\title{
Composition and techniques of the Ticinese stucco decorations from the 16th to the 17th century: results from the analysis of the materials
}

\author{
Marta Caroselli ${ }^{1 *} \mathbb{D}$, Stefan Zumbühl${ }^{2}$, Giovanni Cavallo ${ }^{1}$ and Thierry Radelet ${ }^{3}$
}

\begin{abstract}
This work investigated the techniques used for creating a three-dimensional stucco decoration. During the multidisciplinary project "The art and industry of Ticino plasterers from the sixteenth to the seventeenth century", some stucco works mainly situated between the south of the Ticino region and the province of Como were studied. These artists traditionally known as "Masters of the Lakes", were invited across Europe to decorate the most important architectures at the time. The diffusion of this art and in particular of these workers was probably due to their unique ability to master the complex art of stucco. In particular, the scientific research was addressed at understanding the structure, composition and original "recipes" of the high relief stucco and statues, by using different complementary analytical techniques: the internal structures were analyzed with the radiographic technique, the mortars were characterized by polarized light microscopy, SEM-EDS and FT-IR spectroscopy. The identification of organic additives was possible thanks to a pre-treatment sample with the reactive sulfur tetrafluoride gas $\left(\mathrm{SF}_{4}\right)$. Our results indicated that the stucco works of the considered authors were made using almost all recurring components, although differences emerged in the assembly of the internal structure, in the presence of gypsum in the ground mortar layers and in the use of the aggregate in the finishing.
\end{abstract}

Keywords: Stucco decorations, Gypsum, Mg-lime, Building conservation, Mortar petrography

\section{Introduction}

Stucco is an ancient artistic technique, widely experimented since the classical period, which uses mixtures mainly based on lime, sand and marble powder, to create architectural decorations and three-dimensional works in imitation of marble sculptures [1]. The so-called "Masters of the Lakes" or "Magistri Comacini" are famous stucco makers from northern Lombardy (Italy) and southern Ticino (Switzerland), requested throughout Europe between the sixteenth and eighteenth century, in major construction sites. During the winter break they returned to their homeland, where fundamental evidence of their artistic ability was left. Despite numerous publications have studied their cultural context [2-5], the technical aspect of their works has been little investigated [6-10]. With the project "The art and industry of plasterers of Ticino from the $16^{\text {th }}$ to the $17^{\text {th }}$ century"1 this topic was targeted by analyzing the stucco works of the most important artists from the Canton Ticino in their places of origin, in that specific period (Additional files 1-14).

\footnotetext{
*Correspondence: marta.caroselli@supsi.ch

${ }^{1}$ Institute of Materials and Construction (IMC), University of Applied Sciences and Arts of Southern Switzerland (SUPSI), Campus Trevano, CH-6952 Canobbio, Switzerland

Full list of author information is available at the end of the article
}

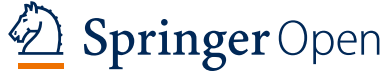

(c) The Author(s) 2020. This article is licensed under a Creative Commons Attribution 4.0 International License, which permits use, sharing adaptation, distribution and reproduction in any medium or format, as long as you give appropriate credit to the original author(s) and the source, provide a link to the Creative Commons licence, and indicate if changes were made. The images or other third party material in this article are included in the article's Creative Commons licence, unless indicated otherwise in a credit line to the material. If material is not included in the article's Creative Commons licence and your intended use is not permitted by statutory regulation or exceeds the permitted use, you will need to obtain permission directly from the copyright holder. To view a copy of this licence, visit http://creativeco mmons.org/licenses/by/4.0/. The Creative Commons Public Domain Dedication waiver (http://creativecommons.org/publicdomain/ zero/1.0/) applies to the data made available in this article, unless otherwise stated in a credit line to the data. 


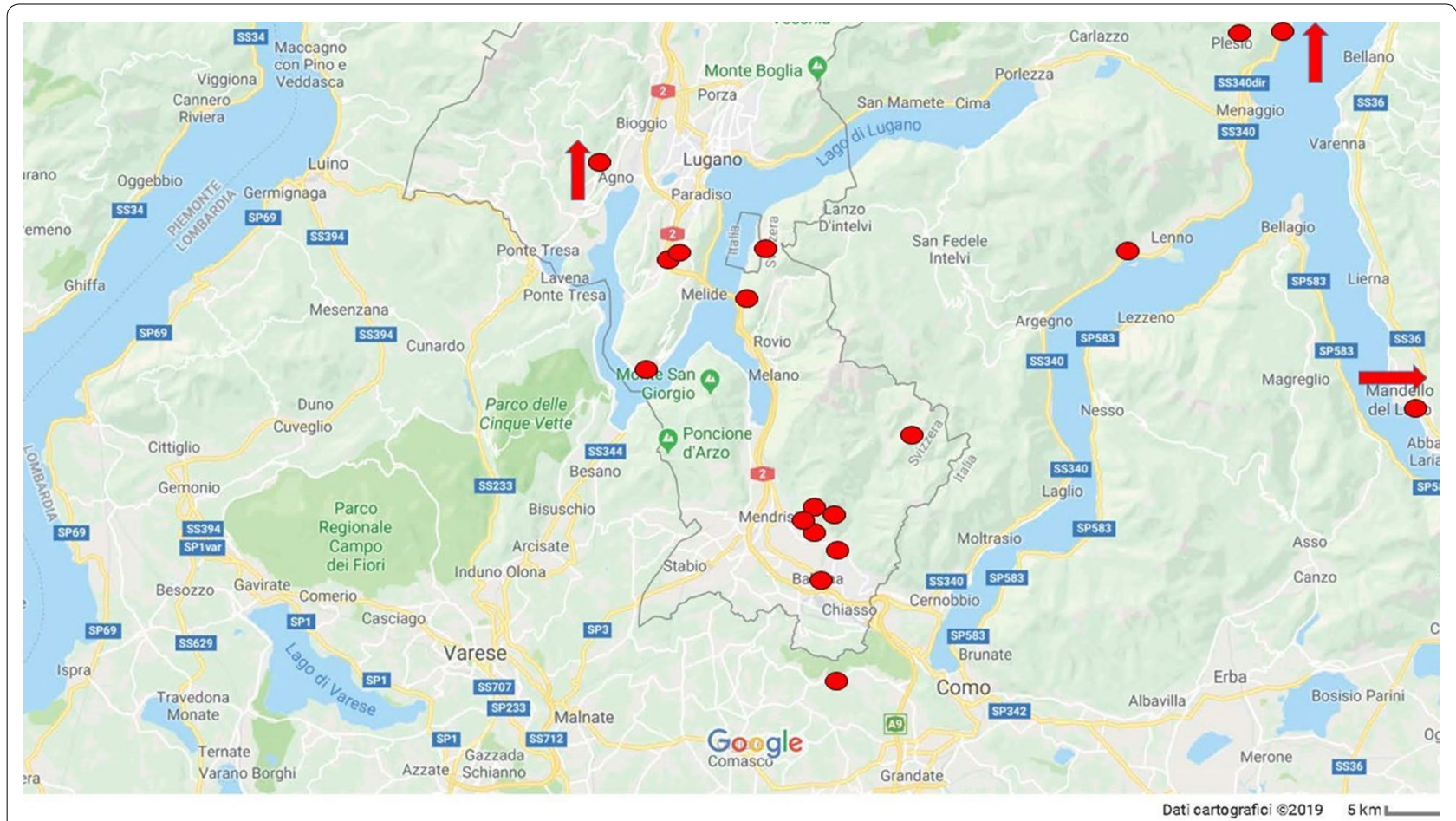

Fig. 1 Maps of the studied area with the analyzed case studies. Please note that some of them are outside of this area (in direction of the red arrow) and they are not included in this image

The intent was to understand if there was an art of the stucco typical of this region or if each artist interpreted the use of materials and techniques according to individual rules and procedures. While the historical and cultural implications have been addressed by other lines of research within this project [11], this paper focuses on the scientific study of the materials. In particular, two questions have been posed: (i) what information is it possible to obtain through scientific analyzes regarding execution techniques and at what level of detail and (ii) if there are similarities between materials and techniques used by different families, or if some distinctive and peculiar characteristics of each workshop can be identified.

To enable comparisons among works and artists, the research was limited within a specific period and geographical context, located mainly in the area of Lugano, Mendrisio and Como, (Fig. 1). Furthermore, the researches were concentrated on well-known artists, such as the Silva from Morbio Inferiore, the Casella from Carona and the Colomba from Arogno, because there were already excellent historical and artistic studies that have provided the necessary basis to contextualize the collected data [12-14]. Twenty sites were documented and sampled (Table 1). The case studies were selected among the high number of works of the area, giving priority to the ones featuring archival documentation, or to the most easily accessible (thanks to ongoing restoration works or by mounting scaffolding).

The investigations were focused almost exclusively on mortars and internal structures because polychromies, gilding and surface treatments have often been profoundly modified during restoration or renovation works.

\section{Brief description of families and case studies}

The case of the Silva family is particularly significant because of their extraordinary works. Francesco (1560? -1643 or 1649), Agostino (1628-1706) and Gianfrancesco Silva (1660-1738) - father, son and nephew-are the prominent members of this family. They were active as a small family business, with Agostino, who began his career when Francesco's was about to end working, expanding their fame beyond the Ticino region to northern and central Italy, and with Gianfrancesco who collaborated for a few years with his father, before finally moving to Germany [15]. Their work is highly represented in the region and many case studies were deeply analyzed (Table 1).

The churches that have been examined more in detail are Santa Maria dei Miracoli Church in Morbio Inferiore (stucco decorations by Francesco, Agostino and Gian 
Table 1 According to [34] Sand: very coarse 1-2 mm, coarse 0.5-1 mm, medium 250-500 $\mu \mathrm{m}$, fine 125-250 $\mu \mathrm{m}$, very fine 62.5-125 $\mu \mathrm{m}$

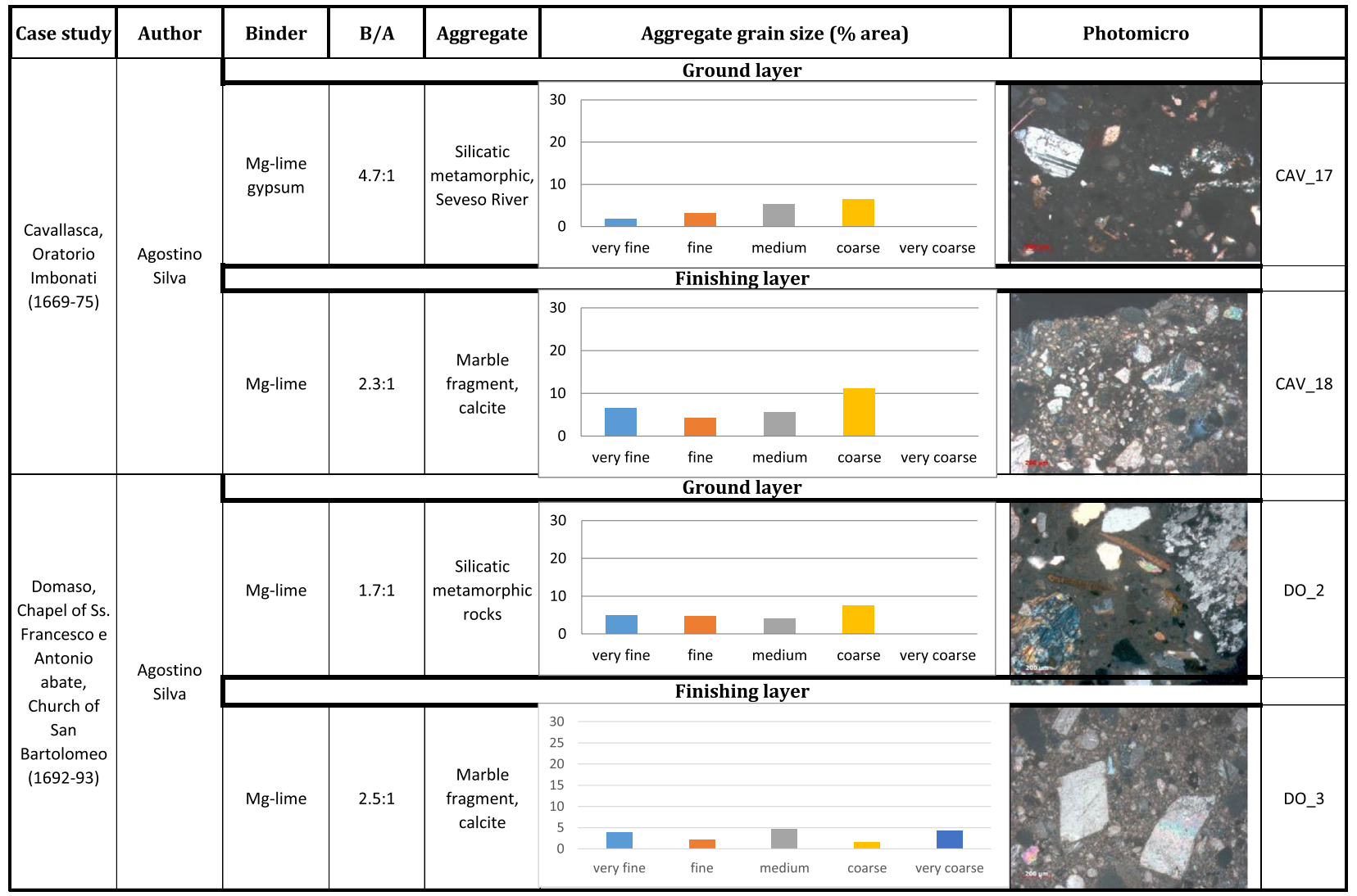

Francesco Silva), the Oratorio Imbonati in Cavallasca (CO) with stuccoes attributed to Agostino, the church of San Salvatore in Vercana (CO) with stuccoes by Francesco e Agostino, the Church of Sant'Eusebio in Castel San Pietro (Ti) with the architectural project and stucco decorations of the Cappella della Madonna by Agostino and his helpers.

The Casella family from Carona included many successful artists, who have worked both in the Ticino region and in Italy: sculptors, stonecutters, architects, painters and plasterers. The activities of the various artists and their family relationships are not very clear due to the lack of documents, so it is difficult to attribute the works with absolute certainty. The plasterer (Giovan Battista Casella, ?-1602) is documented mainly in Rome and only a few of his works are known. Probably in the second part of his career he returned to Carona, where he assumed the leading role in the decorations of the church of SS. Giorgio and Andrea (stucco of 1591). Alessandro Casella (1596-1657) is the author of a large number of stucco works in Valtellina where he worked in the $1620 \mathrm{~s}$ with the artist Bernardo Bianchi from Campione d'Italia (around 1596-1663), but it is not easy to distinguish each specific contribution to their works. Between 1646 and 1648 Alessandro was engaged as an important artist at the court of the Savoia. The church of San Giorgio (Giovan Battista Casella 1579-1591) and the church of Santa Maria d'Ongero (Alessandro Casella, 1630-48) in Carona were considered as representative of their works; the Church of San Lorenzo in Fusine (SO) was also included even if it is external to the examined geographic area, but well documented.

The Colomba family is formed by the plasterer Andrea (1567-1627) and his son Giovanni Antonio (15851650). The first known artworks are in Brescia while in the Ticino region there are not many well-documented works, as for example the stucco decoration of Giovanni Antonio in the Church of Santo Stefano in Arogno. Giovanni Antonio is also the author of the two statues of San Michele and San Sebastiano (1636-1644) in the Oratory of San Rocco in Bissone. They had a fundamental role in the region and so their works were also selected.

Considering that the commissions were closely tied to a particular family, the decorations were often created by successive generations of artists, allowing useful comparisons of working methods over time. 
Table 1 (continued)

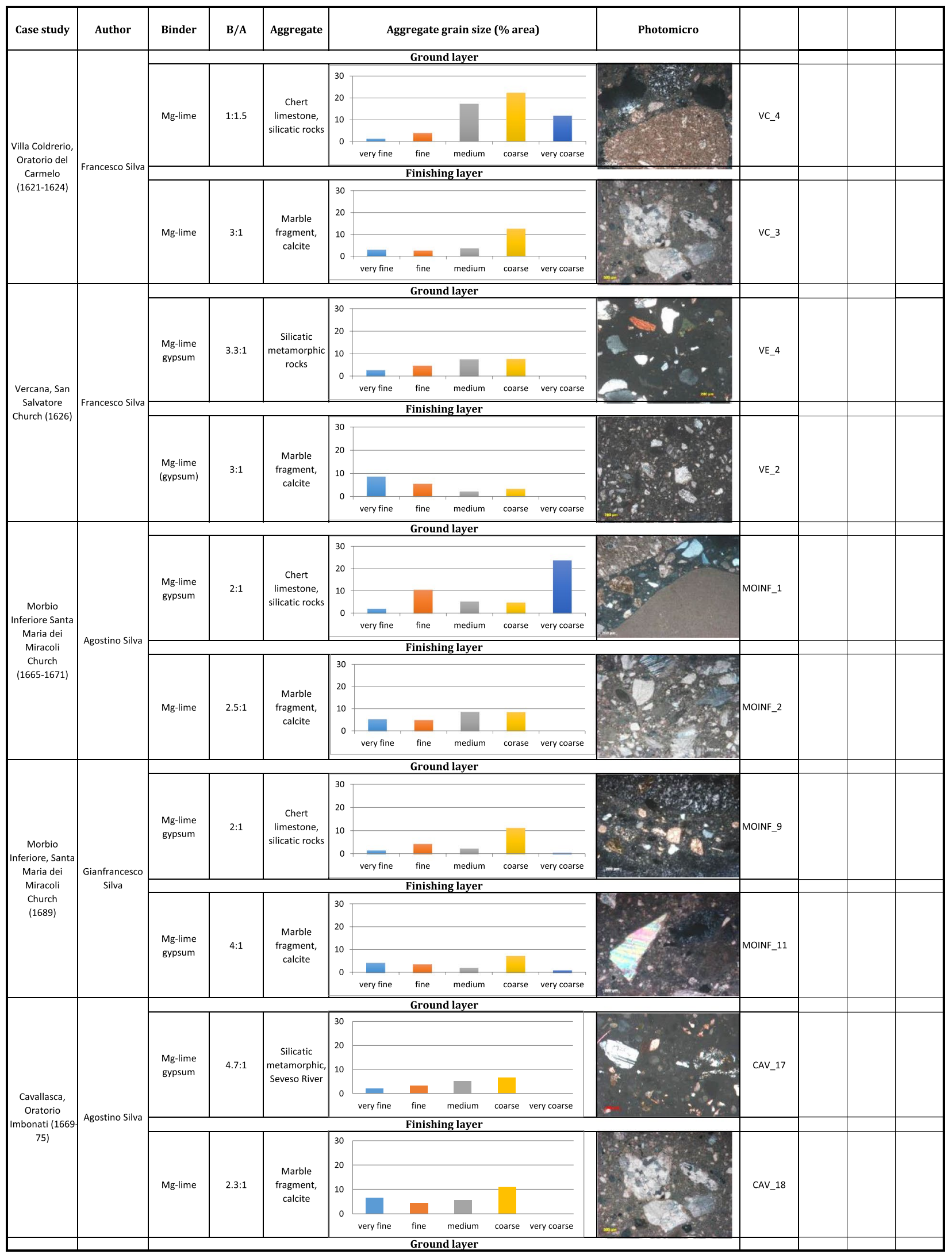


Table 1 (continued)

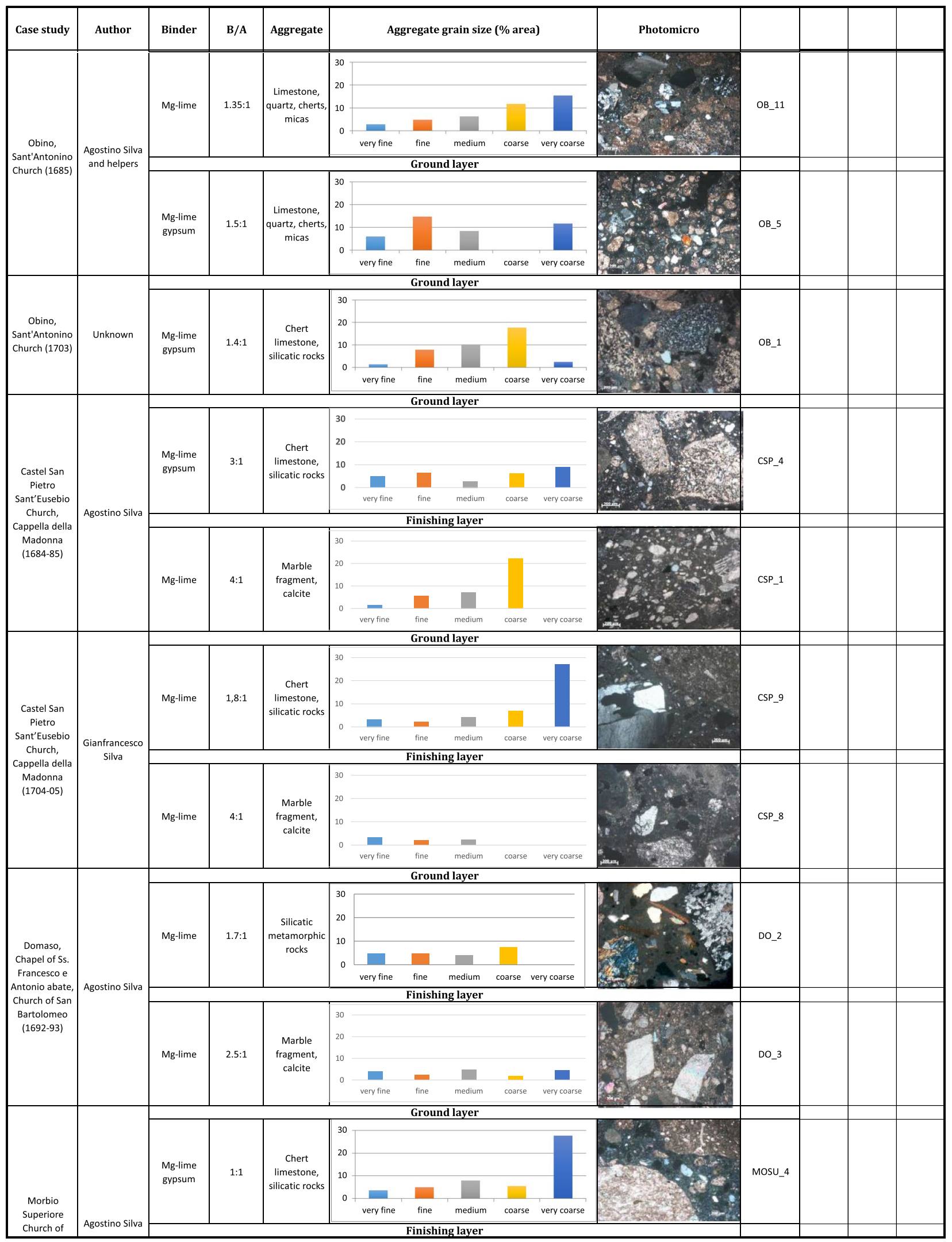


Table 1 (continued)

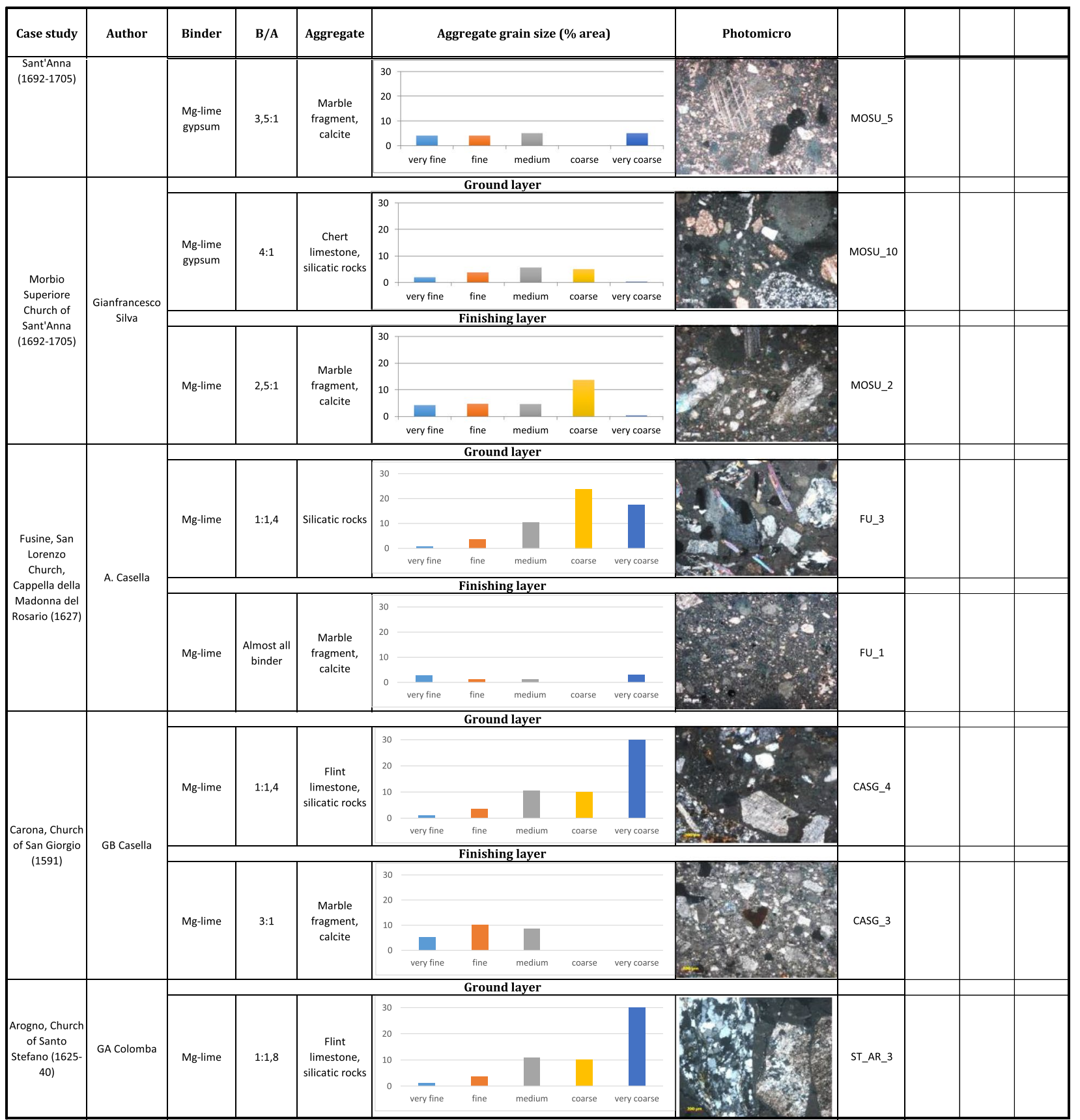

\section{Materials and methods}

The analytical protocol was structured in order to study the technique of the stucco statues made by these artists. Archival and bibliographic research and careful in situ macroscopic observations were first carried out in close collaboration with art historians and conservators-restorers, in order to plan a targeted and systematic collection of the samples. The demands to be taken into considerations were: (i) limiting the number and cost of analyses, (ii) obtaining as much information as possible from small samples, (iii) having comparable results.

In addition to sampling, non-invasive radiographic equipment was used to identify the internal structures of the statues. The detection instrumentation is an indirect digital type, with phosphorus plates $(100 \mu \mathrm{m}, 35 \times 43 \mathrm{~cm})$ which allow to obtain up to 64,000 Gy levels. This parameter improves the performance of the plates in the case of three-dimensional objects, if compared to the analog 
system, because it is possible to obtain information from the different thicknesses with a single exposure, working in post-production on the contrast of the images. The $\mathrm{X}$-ray source used is Eresco 42MF 3.1, 5-200 kV and the scanner is DURR CR35 NDT. The radiographic analyzes were conducted on sites to represent each analyzed family, and so from the Oratorio Imbonati in Cavallasca and the Church of Sant 'Eusebio in Castel San Pietro (Silva), the Church of Santo Stefano in Arogno (Colomba), and the Church of Santa Maria d'Ongero in Carona (Casella).

The petrographic analyses on the 250 samples were the basis of our research; a number significantly higher than that considered during similar research projects, ${ }^{2}$ but necessary to trace significant variations and/or similarities in the stucco technique. The mortars, but even more the stuccoes, are very heterogeneous and composite materials, in which important differences emerge not only within the same case study but also within a single element, if we consider the small scale of a sample (maximum about $2 \mathrm{~cm}^{3}$ ) that could be taken from an area. In order to obtain statistically relevant results, 2 samples were taken for each decorative element and, where possible, including all the different layers distinguishable with the naked eye. In case of uncertain attributions or multiple authors, an attempt was made to characterize at least one element per author. The sampled areas were chosen in parts that cannot be visible to the public (e.g. from the back of the statues or from hidden elements).

To characterize historical mortars, the results from the various scientific methodologies, such as chemical, mineralogical, petrographic or physical ones, must be combined to obtain a complete characterization of the material. Nevertheless, the petrographic approach demonstrated to provide the greatest quantity of information [16] and the integration with software for image analysis can overcome the limit connected with a qualitative description. Polarized light microscopy of thin sections was used for the study of the stratigraphy and application methods, sand type and distribution, and the characteristics of the binder. The image analysis associated to petrography, uses a software (Image J) to quantify the different components of the mortar in thin section (binder to aggregate proportions, sand grain size, porosity, lime lumps and gypsum residues) and through algorithms it is possible to calculate,the areas and other geometric parameters to characterize the mortar texture [17]. A Zeiss Axioskop 40 microscope coupled with a digital camera system (Axiocam) was used to document the thin

\footnotetext{
${ }^{2}$ L'arte dello stucco nel parco dei magistri comacini (intelvesi, campionesi, ticinesi) delle valli e dei laghi: valorizzazione, conservazione e promozione. Progetto INTERREG IIIA-Misura: 2.2, 2006, Valorizzazione del patrimonio artistico, culturale ed edilizio comune.
}

sections. Images were taken using the AxioCam 4.5 software. Some representative samples of each author in the different case studies have been studied by image analysis (Table 1): three photomicrographs (width approximately $5 \mathrm{~mm}$ ) have been manually redrawn selecting the aggregate, pores and binder related particles. The different proportions of the mortars (binder / aggregate) indicated in Table 1 have been quantified considering the surface occupied in a thin section, in order to have a comparison parameter, but the results are not intended to establish the real proportion of materials used by the artists.

A JEOL 6010-LA SEM-EDS (Scanning Electron Microscope coupled with Energy Dispersive Spectroscopy microanalyses), was used to investigate the elemental composition of the individual layers and to study the morphology and texture of the mortar binder. Using a back scattered electron (BSE) detector, images were acquired at $15.00 \mathrm{kV}$ voltage and 45 and $200 \times$ magnifications. EDS spectra and maps (K-lines) were obtained on relevant locations using the following acquisition conditions: Volt $15.00 \mathrm{kV}$, Process Time T3, Live time $90.00 \mathrm{~s}$.

The FT-IR (Fourier Transform Infrared Spectroscopy) was used as a preliminary and quick tool to characterize the binder of the stuccoes: both the gypsum and the lime (and their relative proportions) can be easily pointed. In specific cases the Mg components of the dolomitic lime were also identified (e.g. peaks referred to magnesite and/ or hydromagnesite). ATR-FTIR (Attenuated Total Reflectance FT-IR) was performed with a Perkin Elmer UATR (Single Reflection Diamond) "Spectrum two" spectrometer on solid samples. The instrument uses a MIR source, a diamond crystal, an OptKBr beam-splitter and a LiTa03 based detector. Spectra were acquired within the 4000$400 \mathrm{~cm}^{-1}$ range at $4 \mathrm{~cm}^{-1}$ resolution and 32 scans.

The determination of the presence of organic material is rather complicated by FT-IR [10, 18], both because the percentage of the additives is usually low and negligible compared to the total, but also because of the easy degradability of these substances within the alkaline fresh stucco paste. To improve its spectral selectivity, an extraction and derivatisation technique were used in combination. For the extraction, $1 \mathrm{~g}$ of stucco material was ground into fine powder. The used amount of material corresponds to a sample size of about $1 \mathrm{~cm}$. The powder was then mixed with $10 \mathrm{~g}$ of distilled water and suspended in an ultrasonic bath for a few minutes. The powder was sedimented overnight and the clear solution was then filtered with a $0.22 \mu \mathrm{m}$ millipore filter. The clear solution was then evaporated on a microscope slide. In this way the organic components can be concentrated. But, since lime and especially gypsum $(2.4 \mathrm{~g} / \mathrm{l})$ are slightly soluble as well, the sample not only contains the water-soluble organic compounds but also some inorganic residues. For 


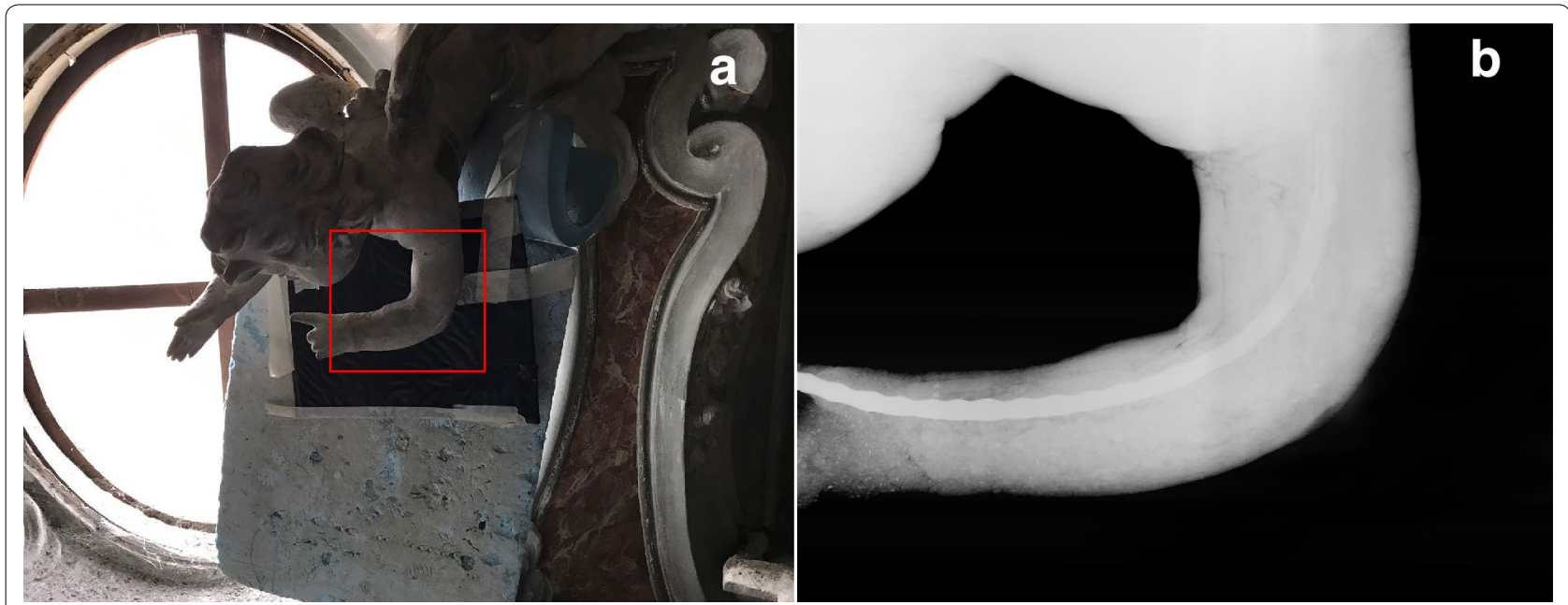

Fig. 2 Castel San Pietro, Church of S. Eusebio, chapel of S. Antonio, 1748-55, stucco made by Francesco Pozzi. a Visible light picture of the area (in red) where the radiographic detail was taken; $\mathbf{b}$ Radiographic detail of the putto where it is possible to observe the squared section of rods, riveted in an alternating direction to guarantee a better adhesion with the mortar

the detectability of minor components or for trace analysis, the signal overlaps of the inorganics can be a problematic. To improve its spectral selectivity, an extraction and derivatisation technique were used in combination. This sample pre-treatment is necessary to eliminate or the interfering signals. At this purpose the active gas sulphur tetrafluoride SF4 was used according to the procedure described in [19]. As example, it is a helpful method to eliminate carbonate signals and the disturbing signals of gypsum can also be reduced. For these analyses a Bruker Lumos system with an MCT detector was used. The measurements were taken with a spectral resolution of $4 \mathrm{~cm}^{-1}$ and 64 scans. Sixteen samples were selected from six case studies to represent all the plasterer from the considered families. The samples were chosen together with the restorers after careful visual analysis, in order to intercept the elements with plastic shape and little aggregate, where therefore the use of an organic additive could be functional. In addition, samples were chosen from both the finish and the ground layer.

\section{Results}

The close observations made by conservator-restorers of the stucco sculptures showed that their creation took place directly on the wall. Their support structure is mainly composed of bricks fixed to the masonry, whose shape is pre-set according to the type of object and constitutes the pivot of the designed composition. After that, the metal structures are inserted and fixed, then glued with an adhesive mortar, creating the first rough appearance.

\section{Radiography}

Radiographic investigation has provided information on the executive technique by identifying some of the elements that constitute the internal structure of the stucco works and their assembly method. Even if this technique cannot be exhaustive due to the radiopacity and the thickness of the mortars, which limits the reading of the lighter elements, the resulting images have made it possible to distinguish at least the metal elements. The presence of wire rods to compose the skeleton is a common element in all the analyzed statues. The rods are forged iron bars of square section, riveted on the sides in an alternating direction, of different sizes from 6 up to $15 \mathrm{~mm}$. This particular treatment of the iron bars could guarantee a better adhesion with the mortar and thus satisfy the specific requests of the plasterer: the malleability makes it possible to bend them during the work, while rigidity and strength must be sufficient to support the protruding loads. In some cases (Fig. 2a, b), the wire rod is the only metal element used and it is modeled to follow the shape of the putto's arm.

In other cases, the structure is made of several metal wires intertwined to form a robust structure or used as a single element in the subtler areas, such as the heads or fingers of some statues. This method of creating the internal structure is recognized in one of the statues of the Church of Sant 'Eusebio in Castel San Pietro (Fig. 3a, b).

Radiographic investigations also revealed the use of thinner iron wires used for different purposes. They are mainly used to tie together various elements that make up the internal structure of the statues, or as a basic skeleton for fine elements such as fingers (Fig. 4a, b) or dress 


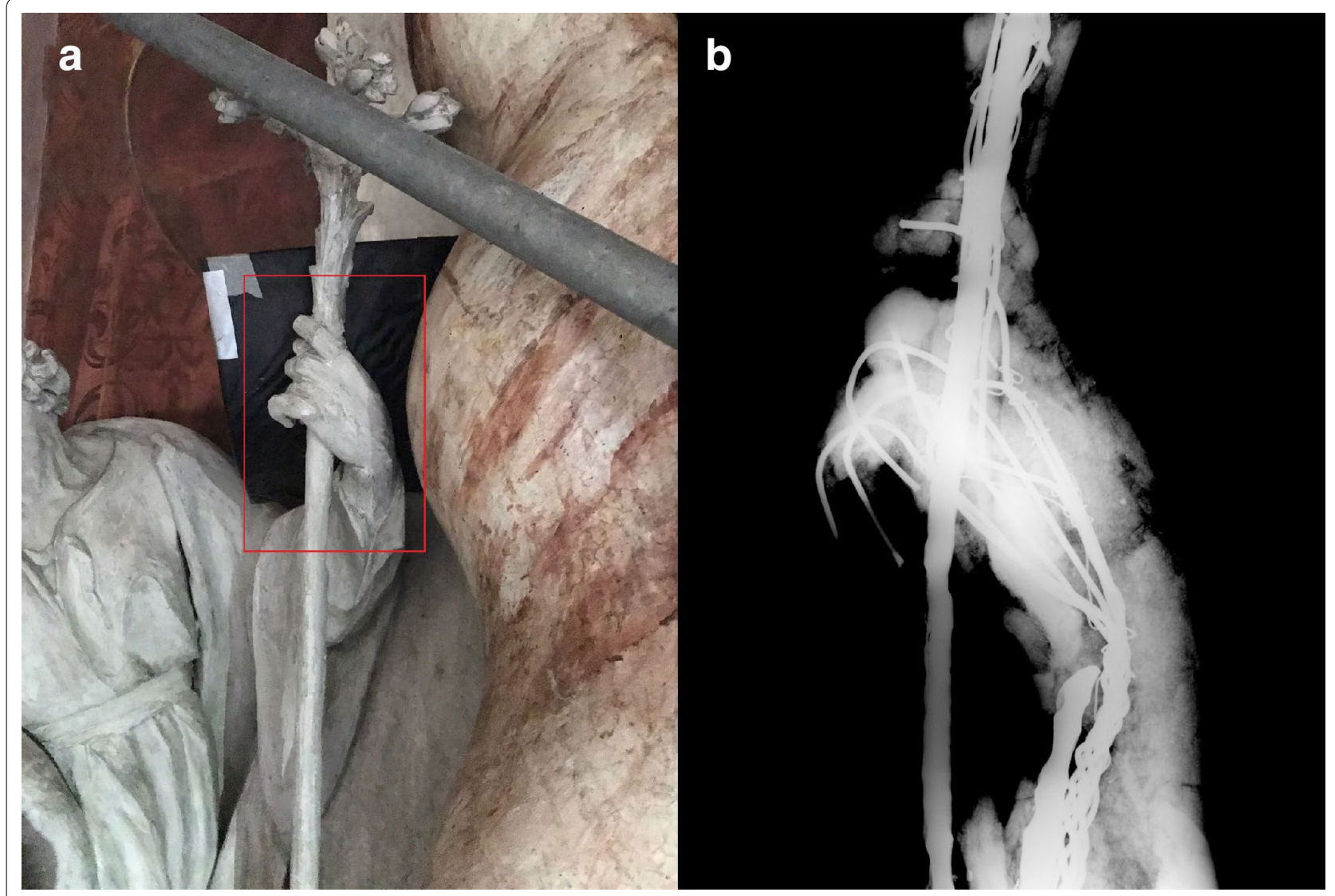

Fig. 3 Castel San Pietro, Church of S. Eusebio, Cappella della Madonna, San Giuseppe statue by Agostino Silva, 1685. a Visible light picture of the area (in red) where the radiographic detail was taken; $\mathbf{b}$ Radiographic detail in which it is possible to see the construction of a hand: the structure is made of several metal wires intertwined to form a robust structure to be fixed to the arm, while in the fingers the wires are used as a single element

and wings (Fig. 4c, d). The iron wires were also used to set the volume of some figures such as the leg of the putto (Fig. 4e, f). It is likely that other non-radiopaque materials are contained within one tangle of iron wire, such as for example straw or fabric. Furthermore, it was possible to document the use of the nails, although to a lesser extent than the other two metal elements. In Fig. 5a, b it can be seen how it was used together with the rods for the construction of the internal structure of the statue.

In addition to the identification of the internal structures, the radiographic technique has made it possible to differentiate the consistency of the mixture with which the stucco statues are made of: in some cases, it is more compact while in other the individual grains and voids are recognizable (Fig. 6a, b).

In particular, the radiographic investigations have allowed to recognize signs of decay such as internal cracks. They are recognizable as less radiopaque than the rest of the statue. Figure 7a, b shows an example of arm subject to numerous internal cracks not visible with the naked eye, both pronounced cracks and very small ones.

\section{Petrography of stucco mortars}

Most of the analyzed stucco showed a similar stratigraphic sequence (Table 1): a ground layer (strato di corpo) to create the volumes and a finishing layer, with a decorative purpose of giving the artwork a marble statue aspect. The binders used for the ground layer are Mg-lime alone or mixed with gypsum. The binder of the finishing layer is always only $\mathrm{Mg}$-lime, even if, in some cases, the addition of small quantities of gypsum was detected. Rarely and mainly for the production of festoons, the stuccoes are executed using a single layer with intermediate characteristics between a ground and a finishing layer (for example in the San Bartolomeo Church, Domaso).

The study of the potential supply sources of the raw materials was done comparing the geology of the area with the petrographic evidence, also following the principle that the traditional production process leaves traces into the historical material. The lime in the Insubric area was obtained by firing dolomitic limestones and carbonate rocks, very common and easily available in the region 


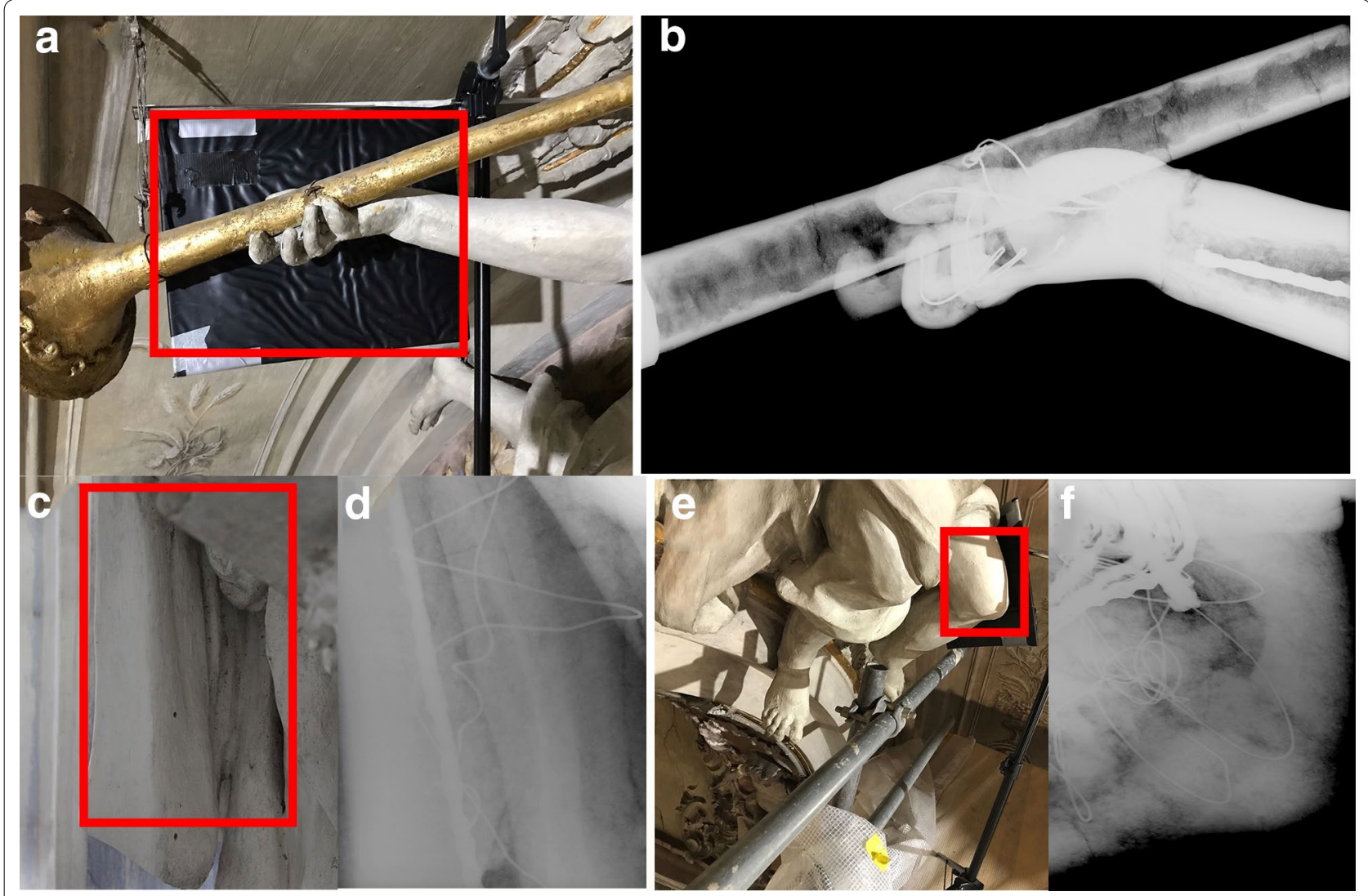

Fig. 4 Radiography detail of statues to show the use of thinner iron wires for different purposes: a Castel San Pietro, Church of S. Eusebio, by Antonio Carabelli, triumphal arch, 1685. Visible light image. b Radiographic image same place of (a). Basic skeleton for fingers; c Cavallasca, Oratorio Imbonati, datail of a statue by Agostino Silva. Visible image. $\mathbf{d}$ Internal structure of the dress shown in (c). e Castel San Pietro, Church of S. Eusebio, by Antonio Carabelli, triumphal arch, 1686-87. Visible light image. f Radiographic image of (e); the iron wires are used to set the volume of the leg of the putto

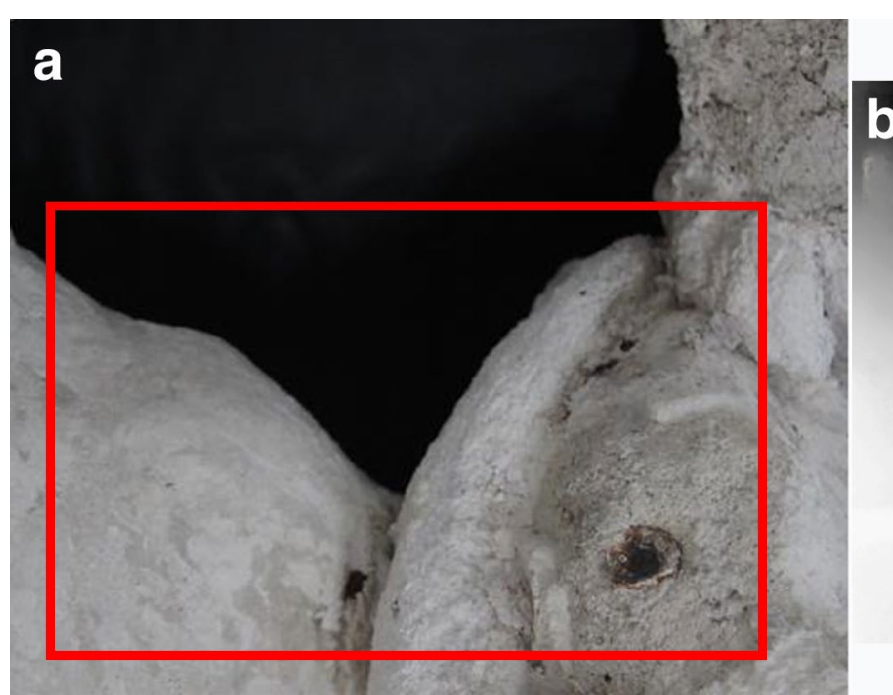

Fig. 5 Cavallasca, Oratorio Imbonati detail of a statue by Agostino Silva. a Visible light image. b Radiographic image of a A: nails and rods are used together 


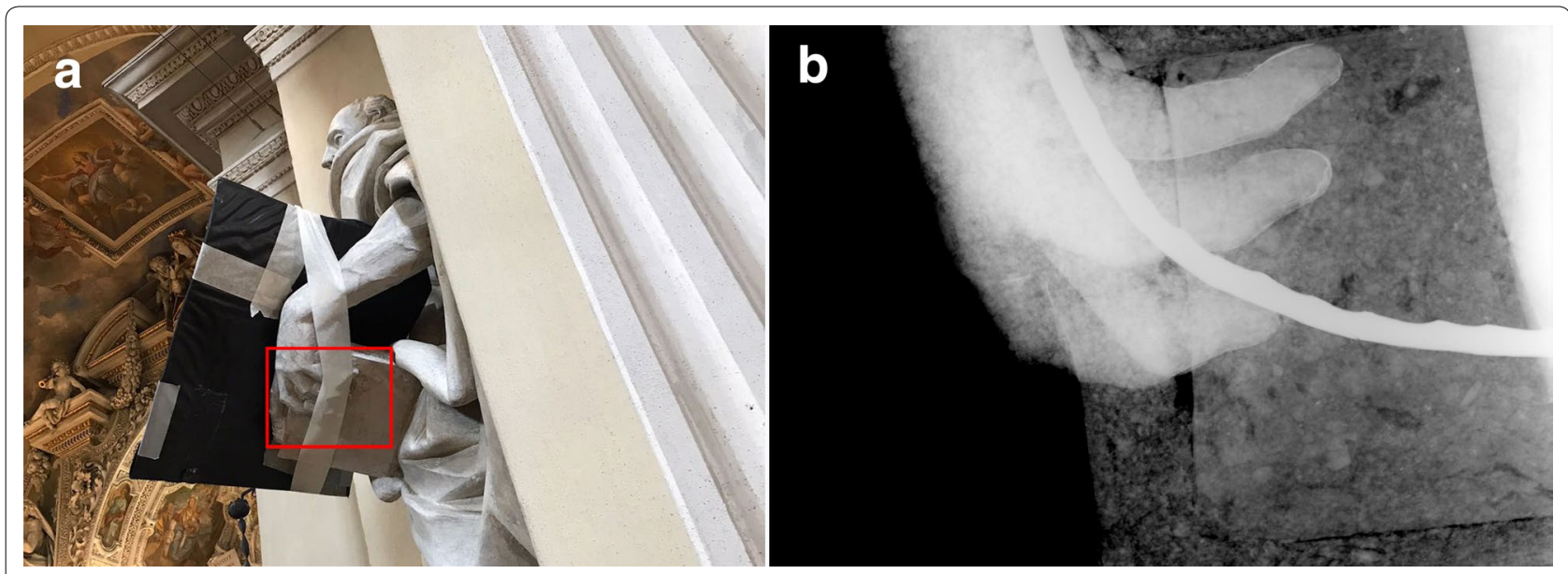

Fig. 6 Arogno, Church of Santo Stefano, a visible light image of a statue by Antonio Colomba. b Radiographic detail of A, where is possible to differentiate the consistency of the mortar: in the hand it is more compact while in the body grains and voids are visible. It is also possible to identify the presence of a brick, with a squared shape

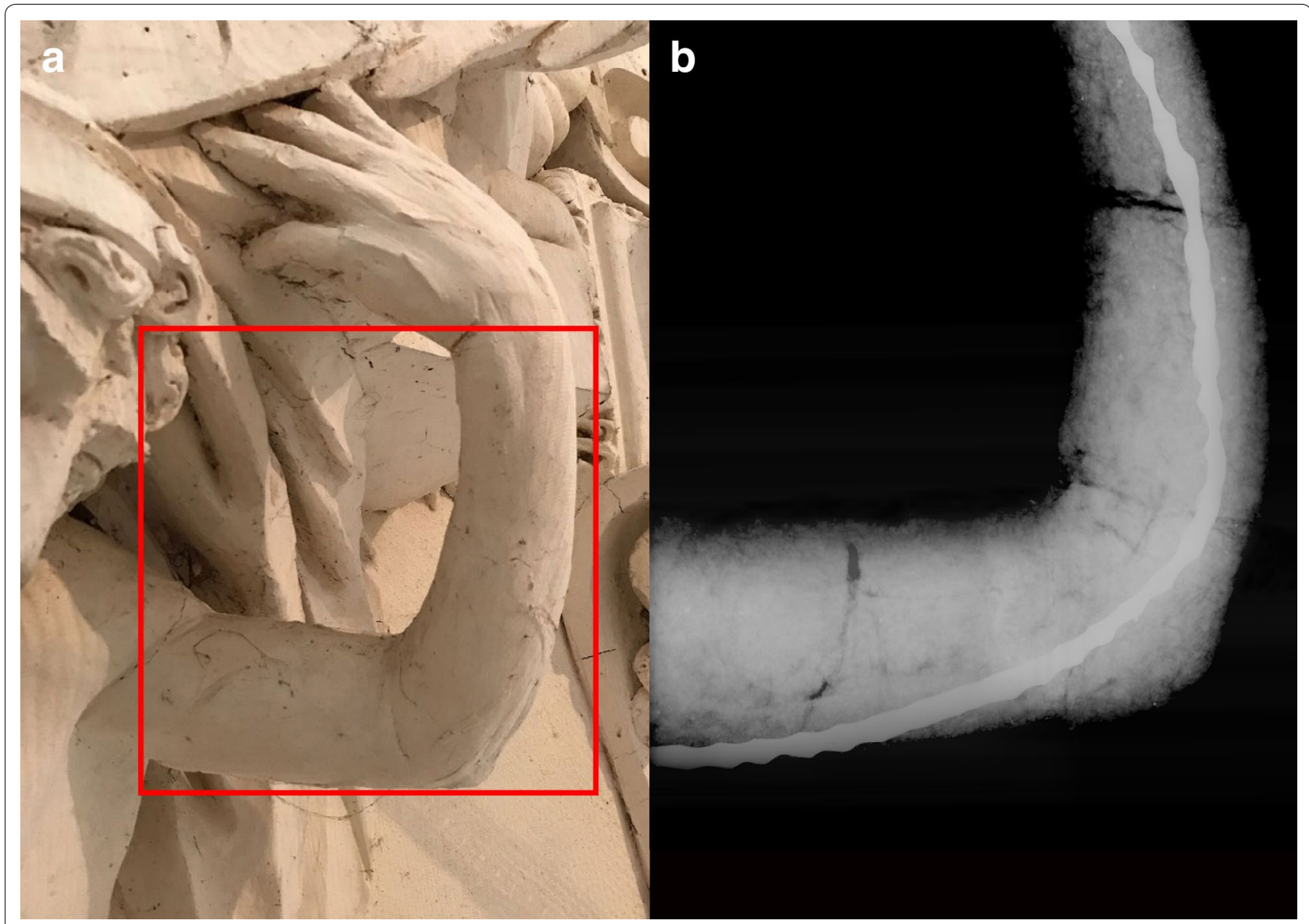

Fig. 7 Carona, Church of Santa Maria d'Ongero, Statue by Alessandro Casella. a Visible light image of the area where the radiographic detail was taken. $\mathbf{b}$ Radiographic detail of the red area of $\mathbf{a}$, where internal cracks are visible inside the arm 

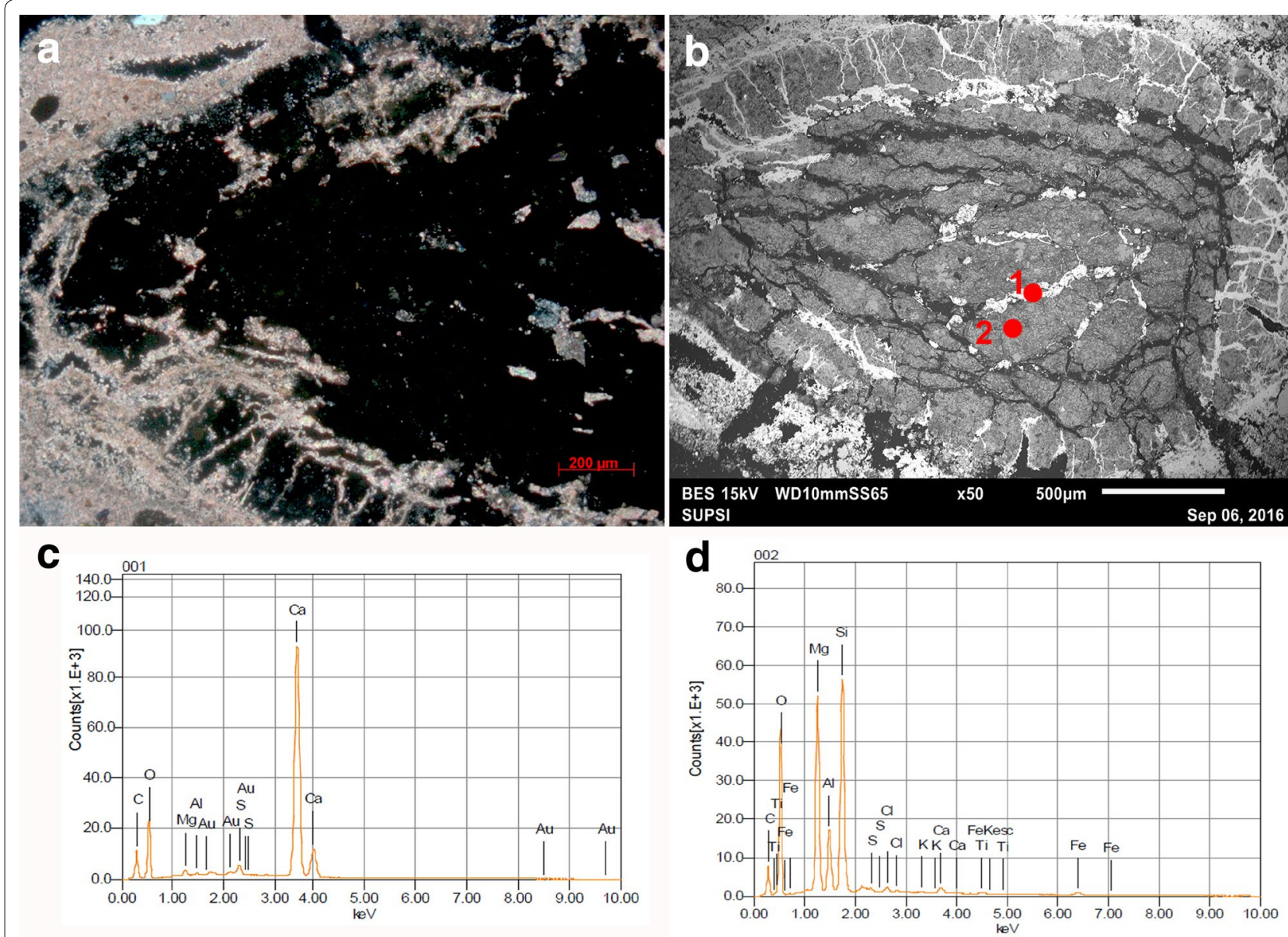

Fig. 8 Overburned binder related particle with a glassy structure in sample CV-04. The glassy part is rich in Mg and Silico-aluminate phases, but there are newly formed calcite crystals within fractures and veins. The Au content in the spectra is due to the metallization of the sample. a transmitted light crossed polars; b BSE image with the indication of point 1 (corresponding to spectrum C) and point 2 (spectrum D); $\mathbf{c}$ Elemental analyses of point 1 (calcite filling micro-cracks). $\mathbf{d}$ Chemical analyses of point 2 (amorphous part rich in Mg-Si-Al)

[20]. This was confirmed with FT-IR (not presented here) and SEM-EDS (Fig. 8). Only in the Sanctuary of Ossuccio (Co) we find the use of high calcium lime in the stucco, attributed to Agostino Silva [8].

BRPs (Binder related particles according to [21]) of both lime and gypsum, were carefully observed in order to gain information about raw materials, firing condition and production technology. Concerning the lime, the results show the high presence almost exclusively of lime lumps sensu strictu while both overburned or underburned lumps [21] are very rare (Figs. 8 and 9). This may indicate a skilled managing of the raw materials firing process or a good selection after combustion.

The binder of the ground layer of a stucco often contains also gypsum. In this case the raw material quarries closest to the Ticino area are located on Lake Como, Nobiallo and Limonta [22] and now abandoned. In addition to these two important sites, some texts mention the
Melide's pinkish gypsum and the "beautiful silky fibrous" from Rogno above Campione [23]. Other limited outcrops were located in the area around Meride where the exploitation started in nineteenth century [24]. The traditional firing process of gypsum, often made directly on site [25] produced an inhomogeneous binder where gypsum stone residues and impurities are frequently observed. The frequent presence of underburned gypsum residues indicates a general low firing temperature. The presence of gypsum in the stucco mixture strongly modifies the characteristics of the mortars, limiting the risk of cracks during the setting phase, as the gypsum increases in volume and retains the molded shape quickly. The addition of gypsum also influences the workability of the mortar and therefore affects the artist's working time. For this reason, it was often used in the ground layer for high relief elements, while, on the contrary, its presence was not necessary and therefore occasionally detected, in 


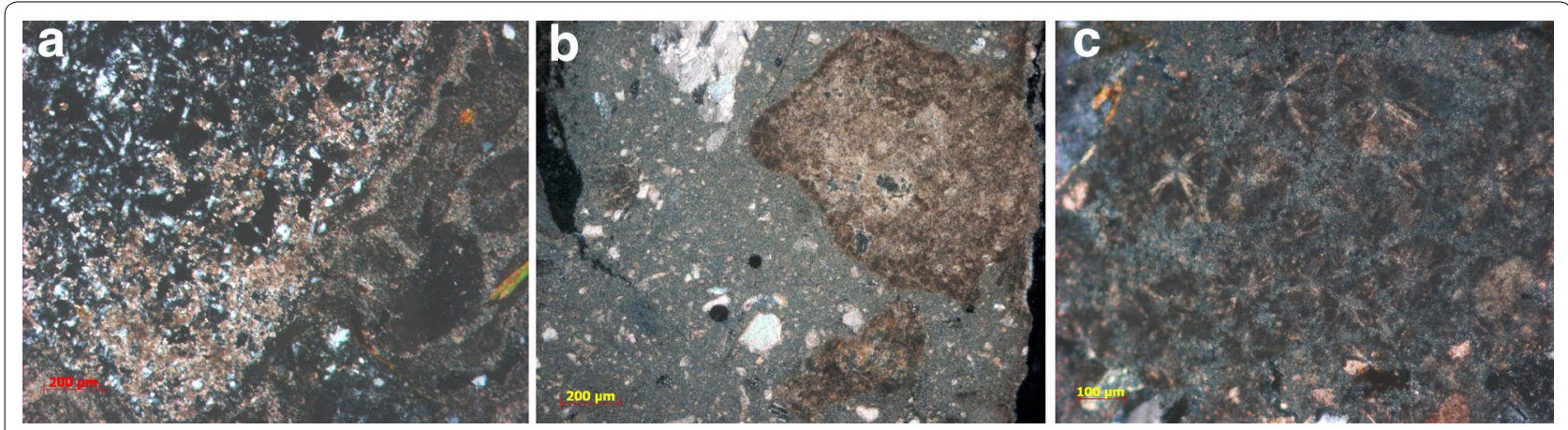

Fig. 9 photomicrographs, transmitted light, crossed polars: a sample CV_15, siliceous phases from selciferous limestone belonging to the binder could be observed in one lime lump; b sample CV_11, underburned lime-lumps of sharp-edged carbonate rock fragments. C sample ST_VC_05, anisotropic rounded, rosette-like shape with radial growth, that can be interpreted as hydromagnesite or Mg-correlated phases

the finishing layer. The quantity of gypsum is very variable even in the same stucco element, and in general it decreases from the most inner structure (mortar with glue function) to the outside layer [26].

The petrographic study of the aggregate makes it possible to identify the procurement sand deposit providing information on the production technology (Fig. 10). The comparison of the sand mineralogy found in the ground layers with the characteristic of the local geology allowed understanding the strong link between resources and their use. In particular, the alluvial deposits connected with the Ticino river are composed of silicate sands both as individual minerals (quartz, feldspars, micas, amphiboles) and metamorphic rock fragments. Samples from the Church of San Rocco in Torricella contain sands with these features (Fig. 10d). Similarly, sands coming from the North of Lake Como (Domaso and Vercana) are silico-clastic metamorphic rock fragments, such as gneiss and schists (Fig. 10e). In addition, for the areas close to the South of Lake Como and (partially) of Lugano, both silicate and carbonate sands are available. This feature was highlighted for the sites in the Southern part of the Canton (Castel San Pietro, Morbio Superiore and Inferiore, Obino, Villa Coldrerio) where the aggregates are composed of selciferous limestones and (subordinately) silicate sands (Figs. 10b, c). The aggregate that forms the skeleton of the ground layer of the stucco of Oratorio Imbonati in Cavallasca is a sand, derived from the transport and weathering of metamorphic rocks, with quartz (with ondulose extinction) as the predominant mineral (Fig. 10a). The composition and the geographical proximity suggest that the supply of this material took place from the Seveso river [27]. Finally, the sands used for the ground layer in the stucco decorations at Bissone show an evident correlation with the sands coming from the Morcote peninsula, where the granophyric intergrowth characteristic of quartz and alkali-feldspar is often recognizable (Fig. 10f).

It can be assumed that a specific grain size of the sand was not selected, because all the size classes are always represented. The observed detectable differences can be attributed to the type of sand and therefore to the supply basin. The sporadic presence of impurities such as wood and straw fibers, fragments of charcoal, common in historic mortars, confirm the exploitation from a river [10]. On the contrary, hydraulic reactive aggregates (eg. pozzolanic materials) were never used, only cocciopesto was documented in one single case (Oratorio Imbonati Cavallasca).

The aggregate of the finishing layers, when present, is always crushed calcite both deriving from marble and calcite veins (sparry calcite); quartz was also detected as accessory mineral (Fig. 10g). The maximum grain size is $0.25-0.50 \mathrm{~mm}$. The source for marble powder is probably related to the Musso quarries located in the upper part of Lake Como (Domaso, parish archive, source cit., 20 November 1691). In some cases, a white limewash was applied over the finishing layer.

In general, the Ticino plasterers used much more binder than aggregate in the mixes (from 3:1 to 2:1), both for preparing the ground layer and for the finishing (Table 1). Exceptions exist in that cases where gypsum is not used, where the amount of aggregate increases (as for example at San Giorgio Church in Carona, the Oratorio del Carmelo in Villa Coldrerio and San Lorenzo Church in Fusine). In these cases, fissure cracks can be observed. Surprisingly this is not true for the finishing layer, in which a low gypsum content and the use of a small amount of aggregate, does not determine the formation of cracks, even for few millimeters thickness. Here, the use of organic additive can be then inferred. The original porosity is always low, both for the ground and for the finishing layer, despite their different composition, 

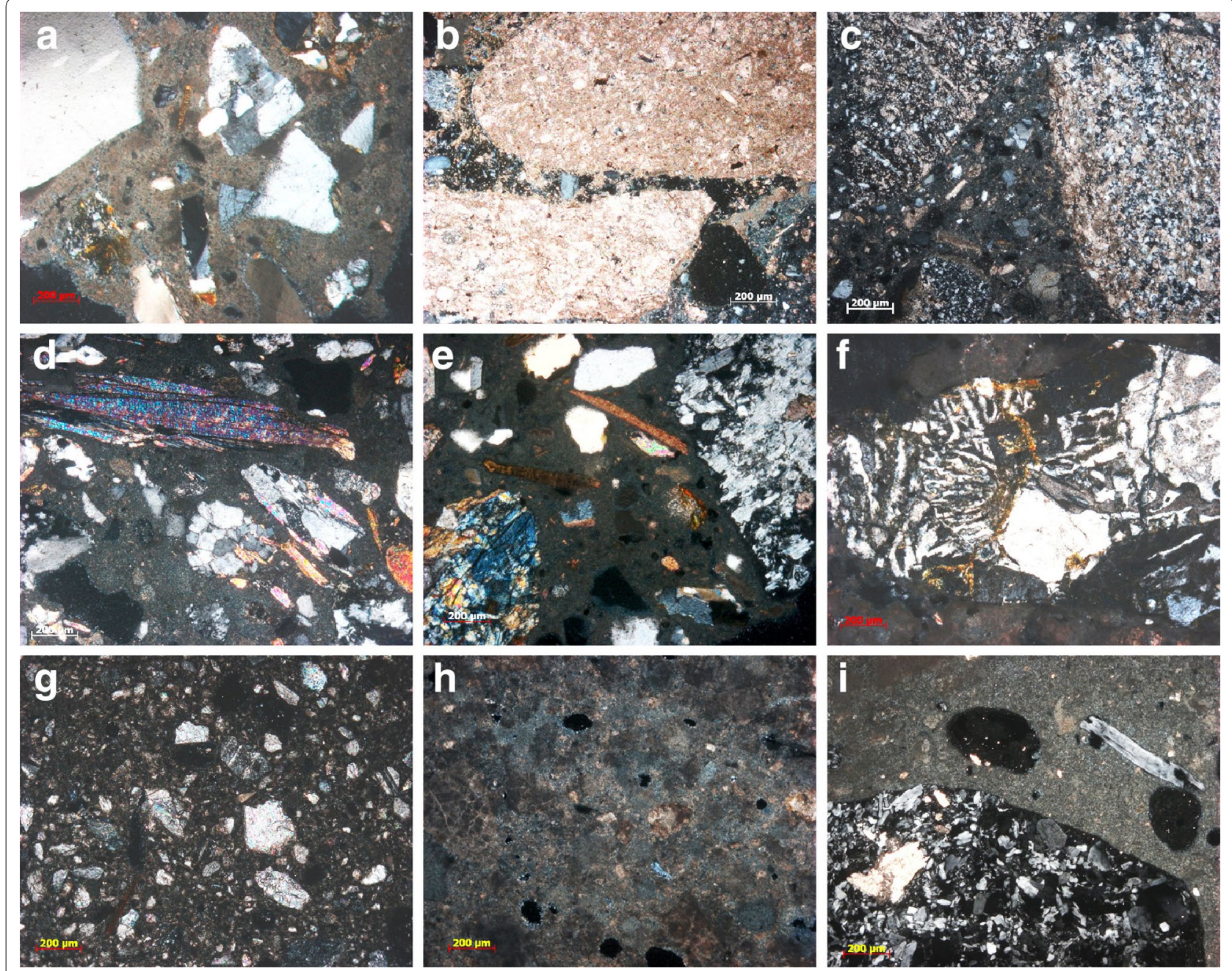

Fig. 10 a Cavallasca, Oratorio Imbonati. Sample CAV_22, silica sand probably from Seveso River. b Villa Coldrerio, Oratorio del Carmelo. The sand is characterised by selciferous limestone. c Castel San Pietro, Sant'Eusebio Church. The sand is characterised by selciferous limestone. $\mathbf{d}$ Torricella, Church of San Rocco. The sand is probably from the river Ticino, composed of silicate sands and metamorphic rock fragments. e Domaso, Church of San Bartolomeo. The sand from the north of the Lake Como are mostly composed of silica sand, fragments of gneiss, schists, quartz in single crystals and polycrystalline, amphibolite and micas. $\mathbf{f}$ Bissone, San Rocco Oratory. The sands come from the Morcote peninsula where is recognizable the characteristic granophyric intergrowth of quartz and alkali-feldspar $\mathbf{g}$ Vercana San Salvatore Church. The finishing layer is composed of marble powder and sparry calcite. $\mathbf{h}$ Arogno, Church of Santo Stefano, sample AR_07. The finishing layer is composed of only binder with frequent lime lumps. $\mathbf{i}$ Carona, Santa Maria D'Ongero. The finishing layer is mostly composed of binder. The gypsum residues are frequent

indicating a great capacity in proportioning the mortar components: this characteristic has limited the risk of degradation, thanks to a very compact and stable material. In fact, severe degradation phenomena have been noted only in the presence of copious infiltrations of liquid water (e.g. Oratorio Imbonati in Cavallasca and Sant'Eusebio Church in Castel San Pietro).

Furthermore, many samples have showed that the finishing layer was applied while the ground layer was still wet, indicating a quick execution technique, made by skilled workers. Indeed, by observing the samples in transmitted light, no signs of carbonation are observed in the transition between the finish and the ground layer.

\section{Infrared spectroscopy (FT-IR)}

The analytical investigations have shown that organic components are present in various samples as shown in Table 2. In most of the cases a protein component (Fig. 11a) containing also lipids were detected (Fig. 11b). While in the evaporated extract, asymmetric and symmetric $v \mathrm{CH} 2$ bands and the $v \mathrm{C}=\mathrm{O}$ (ester) signal are clearly visible and they could possibly be ascribed to lipids, the two amide bands at around $1650 \mathrm{~cm}^{-1}$ (Amid I) and $1540 \mathrm{~cm}^{-1}$ (Amid II) are only visible after derivatisation with sulphur tetrafluoride (SF4). In principle FT-IR cannot be used to determine the protein source. But in this case, egg or some milk proteins can be expected, 
Table 2 Principal FT-IR results

\begin{tabular}{|c|c|c|c|}
\hline Sample & Lipids & Protein & Oxalate \\
\hline \multicolumn{4}{|c|}{ Carona Santa Maria d'Ongero Alessandro Casella } \\
\hline CA_SMO_05A & $x$ & $(X)$ & \\
\hline CA_SMO_03 & & & $x$ \\
\hline \multicolumn{4}{|c|}{ Castel San Pietro Sant'Eusebio, GF Silva or helper } \\
\hline CS_CM_09A & & & $x$ \\
\hline CS_CM_05 & & & $x$ \\
\hline \multicolumn{4}{|c|}{ Ossuccio Sanctuary (unknown author and A. Silva) } \\
\hline ST_OS_06_A & & & $x$ \\
\hline ST_OS_14_A & $x$ & & \\
\hline \multicolumn{4}{|c|}{ Morbio Inferiore Santa Maria dei Miracoli Church (Silva) } \\
\hline MOINF_01_A & $x$ & x & $x$ \\
\hline MOINF_03_A & $x$ & $(X)$ & \\
\hline MOINF 13_A & $x$ & $x$ & $x$ \\
\hline MOINF_15_A & $(\mathrm{x})$ & $x$ & \\
\hline \multicolumn{4}{|c|}{ Bissone Oratorio di San Rocco 1636 (unknown author and GB Colomba) } \\
\hline BIS_SR_08_A & & & $x$ \\
\hline BIS_SR_02A & & & $x$ \\
\hline \multicolumn{4}{|c|}{ Cavallasca Oratorio Imbonati 1669-75 (A. Sllva) } \\
\hline CV_Ol_26 & $x$ & $x$ & \\
\hline CV_Ol_27 & $x$ & $x$ & \\
\hline CV_Ol_27 & $x$ & $x$ & \\
\hline CV_Ol_29 & $x$ & $x$ & \\
\hline
\end{tabular}

which in addition to the protein also contain lipids in varying amounts. In other samples (calcium) oxalates in various concentration were found (Fig. 11c).

\section{Discussion}

Silva

Silva's modus operandi for the realization of the figurative elements can be considered as uniform for the three generations of plasterers. In particular, for the saints or prophets placed within niches, the bricks were clamped in the masonry behind, and the wire rods were inserted to set the "guidelines" of the figures. Additional metal supports were placed directly during the dynamic construction of the figures. The wire rods, grafted into the mortar, were covered with fibers previously soaked with gypsum and lime, in order to ensure better adhesion of the ground mortar layer to the reinforcement. The thinner molded parts, like the hands of the figures, have a refined and accurate armor made up of forged and hardened iron wires, so as to obtain a more rigid metal, covered with string and tow, to create an almost definitive volume on which to only apply the finishing [28].

Of the 143 samples attributed to the Silva family workshop, 113 are those belonging to Agostino's work, who is the most represented author in all the studied area. Of
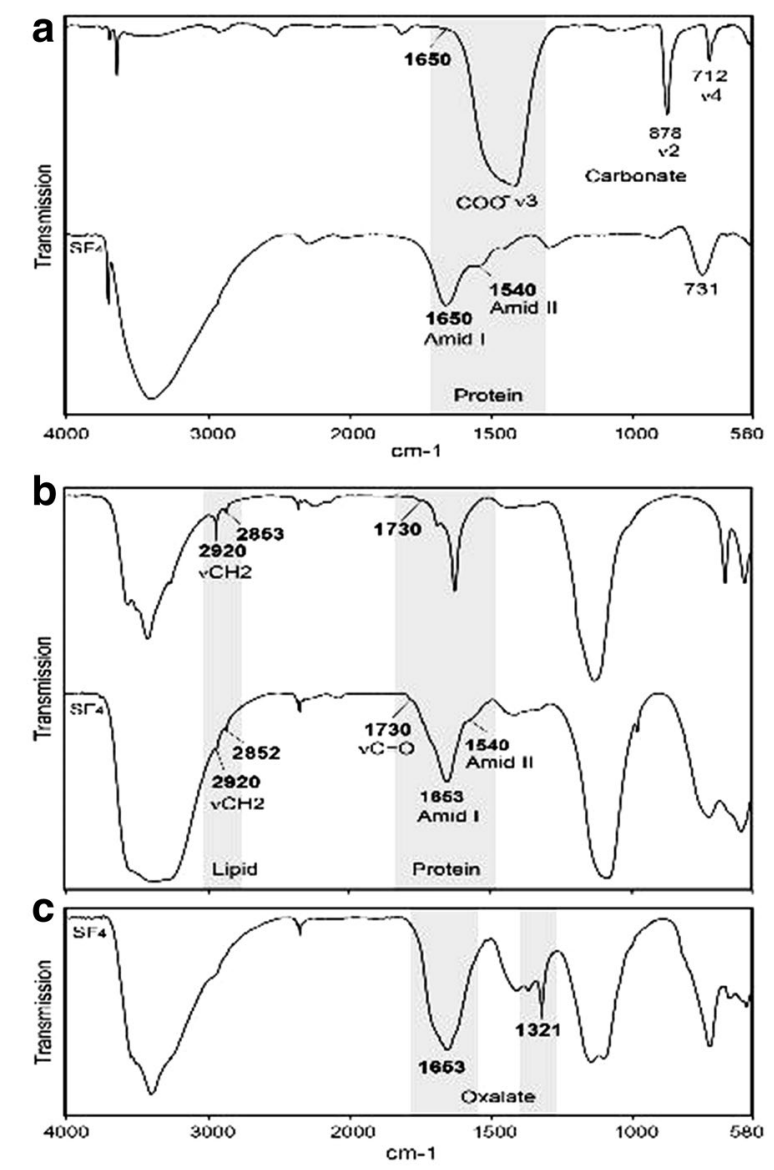

Fig. 11 Analytical results of the FT-IR investigations. The transmission spectra after derivatization with sulfur tetrafluoride are labeled with "SF4". a Example of FT-IR spectrum where a protein component was detected; $\mathbf{b}$ Example of FT-IR spectrum containing also possible lipids; c Example of FT-IR spectrum where calcium oxalates were found

these, 79 samples are from statues or three-dimensional elements. The work of the other two family members was studied with lower number of samples, 22 by Francesco and 10 by Gianfrancesco.

Samples from 3 case studies made by Francesco Silva were analyzed; in 2 of these churches he has worked together with his son Agostino. In both cases the statues are characterized by a ground layer made of Mg-lime and a significant quantity of gypsum, and the aggregate is an unselected local sand. In the Church of San Salvatore, in Vercana, north of Lake Como, the sand is mainly composed of fragments of metamorphic rock and silicate minerals, and the other one, the Oratorio del Carmelo, Villa Coldrerio (in the Mendrisio area) is mainly formed by selciferous limestones. The binder-aggregate ratio is always high (for example 3: 1 in San Salvatore Church, Vercana). The case of Villa Coldrerio is different, but here he did not create statues but only high-relief decorations. 
Gypsum was not used for these elements and the binderaggregate ratio decreases drastically $(1: 1,5)$. The finishes are homogeneous in the 3 case studies: they prevalently contain dolomitic lime binder (sporadic presence of traces of gypsum) with fine marble powder, in proportion $3: 1$.

The composition of the mortars made by his son Agostino, despite a more naturalistic and lively style, with a considerable increase of the overhang of the statues, is maintained similar with comparable proportions. Out of 35 samples of Agostino's ground layer, only in few samples (6) gypsum was not detected. Among these, for example, one sample of Santa Maria dei Miracoli Church, in Morbio Inferiore (sample MOINF 05). However, in the other samples taken alongside (MOINF 06-07), the boundary from lime mortar to lime-gypsum mortar can be seen. This observation strengthens our hypothesis that the powdered gypsum was mixed gradually in the lime and sand mortar [26]. Gypsum is also present in high-relief decorative elements, and only in the highly deteriorated parts of the stucco of the Oratorio Imbonati in Cavallasca, it was not found. For this reason, it was supposed that in these cases the gypsum was originally present but it has been removed through secondary processes [27, 28]. Therefore, according to our results, the use of gypsum mixed with lime was a fundamental ingredient in the innermost layer of the stucco reliefs by Agostino Silva. Moreover, the gypsum as unique binder determines a very sporadic avail of non-selected aggregate. This is particularly true in contact with the iron internal structure where the use of gypsum is almost exclusive.

Gianfrancesco's technique is not as refined as that by Agostino, but regarding the use of materials and relative proportions, it can be compared to the ones of his predecessors, confirming his father's working expertise, in the first years of his career [29].

Most of the stucco samples by Agostino Silva and his family contain organic substances of both lipid and protein origin, therefore it is possible to assert that an organic component was always used as an additive. Since they are mostly found together, the most probable hypothesis is that a single ingredient containing both, such as egg yolk or milk was added. The presence of egg yolk has also been found in the stuccos of other authors from the same area in previous research [30]. Protein alone additives can be found on different objects, which were created over a wide period of time. This widely use of organic additives is not surprising since these were common as processing aids for stucco works [31]. For the Silva workshop in three cases a significant presence of calcium oxalate was observed, at Castel San Pietro,
Santa Maria dei Miracoli Church in Morbio Inferiore and Ossuccio Sanctuary.

\section{Giovan Battista e Alessandro Casella}

GB Casella's only case study in the Ticino region does not allow general considerations. From the Church of San Giorgio in Carona, only 4 samples were analyzed. The ground layer comes from a three-dimensional decorative element (from a coat of arms and not from a statue) and it does not contain gypsum; it has a higher quantity of aggregate than binder $(\mathrm{B}: \mathrm{A}=1: 1,4)$. Despite the greater use of aggregate, porosity is high, with many shrinkage cracks. The sand composition respects the local geology, containing silicates and characteristic aggregates referable to Permian volcanic rocks (Arbostora peninsula). The finishes are similar to those of the Silva's, with Mg-lime and crushed marble.

The stuccoes of the church of Santa Maria D'Ongero, by Alessandro Casella and his workshop, have been studied to identify its internal structures. They are rather unusual because they consist of stones, bricks and tiles of various sizes, assembled disorderly with a lime mortar, with a variable percentage of gypsum and sand, sometimes tied by ropes. The reinforcements and anchors are made with metal brackets of various sizes and in some cases with the use of other materials, such as twine, ropes or vegetable fibers. Organic materials have been used to create the thin and highly protruding parts of the decoration. Inaccurate internal structures have also been highlighted by radiographic investigations that can be one of the causes of the structural instability of the most protruding elements. The wire rods did not show a fabric cover and they are joined together with very thin iron wires, both as single element as well as in small skeins. The fact that Casella cared little for these invisible elements means it's a spontaneous technique, without rigidly following a predetermined form. He knew how to modify and adapt the shape of the model while working. Finally, in general, the small number of iron elements used to anchor the decorations to the masonry point to the use of wood or other radiographic transparent materials [32].

Eighteen mortar samples by Alessandro Casella were analyzed from 2 churches, of which in the Ticino region, Santa Maria d'Ongero in Carona. The lack of testimonies in his homeland led us to move beyond the Ticino region, in order to have more elements to trace the author's possible peculiar characteristics. In the Cappella del Rosario in the San Lorenzo Church in Fusine, Valtellina, he probably worked together with his colleague Bernardo Bianchi in 1627. Big differences are observed in the two case studies. In San Lorenzo Church for the production of the caryatids, he did not use any gypsum, in the ground layer there is more aggregate than binder $(\mathrm{B}: \mathrm{A}=1: 1,4)$ and 
shrinkage cracks are observed. On the contrary, in Santa Maria d'Ongero, the use of gypsum for the statues is very high. Large crystals with limestone impurities and many gypsum underburned residues are observed, sometimes the individual gypsum crystals do not show changes correlated to low temperature or intentional addition to modify the finishing. The finishes are all very similar both in Carona and in Valtellina: while lime lumps in sensu strictu are very frequent, the carbonate aggregate is very scarce and often fine river sand is observed. Despite the limited use of aggregate, the porosity is scarce and rounded. The only different sample is SMO_17 collected from a high relief, which does not contain gypsum. We can formulate the hypothesis of a different technique for the high relief production.

The organic additives were searched only in two samples from Santa Maria d'Ongero and here a different situation was found, because one sample appears to have a fat component and trace of proteins, while the other only shows (calcium) oxalates.

\section{Colomba}

The relief of the decorations of Santo Stefano in Arogno by Giovan Antonio Colomba is not very pronounced without strong overhangs, so there are no particularly complex supports and anchors. The tridimensional statues have a solid and regular structure placed on large shelves. They show a stable barycenter, solidly connected to the back wall. Their support structure is mainly composed of bricks clamped to the masonry and the use of iron reinforcement is very limited. The $\mathrm{X}$-ray images allowed to document their shape and dimensions and it can be seen how essential and functional they are. Their position shows how these reinforcements were built in a very simple and orderly way, creating very effective supports. It should be noted that they are simple and efficient, and the ability in the realization is evident in the very small number of anchors to the wall [32].

Representative samples from stuccoes by Giovanni Antonio Colomba, 9 from Santo Stefano in Arogno and 4 from San Rocco in Bissone, were analyzed. In the ground layer the use of gypsum is sporadic and it is not homogeneously distributed. The quantities are certainly lower than those used by the Silva. The aggregate is mainly a coarse local sand, with high presence of selciferous limestones. The finishing layer is made of only binder with many lime lumps sensu strictu.

In the church of Bissone, (calcium) oxalate was detected. While in the façade sculptures, it is likely that oxalates are ageing products of an organic additive or a contamination from outside, as for example microorganisms [33], for the internal presence further researches are needed to understand their origin.

\section{Conclusions}

Many case studies in the Insubric area with stucco decorations made by plasterers from the Ticino region have been studied for an in depth description of this composite material and its complex technique. The radiography and the characterization of the mortar components and texture were used to identify the production technologies. The aim of this research was to understand if a common modus operandi could be identified or if substantial differences emerged among the different analyzed families.

As regards the possibility of identifying the stuccoes' methods of execution and the origin of the materials, it was possible to draw some general considerations.

- Close observations with scaffoldings have shown that the large statues were always modeled directly on the wall, by means of a first anchoring with bricks, stones or tiles into the wall structure. In this way the authors were able to make most of the stucco artwork, with a particular visual impact that cannot be obtained by a stone carved statue. The artists knew how to use the close link between architecture and decoration, conferring extraordinary illusionistic effects to the spaces.

- Thanks to the X-ray investigation of the stucco statues, it was possible to more precisely identify its hidden internal metal structures. The metal elements were always used by adapting their shape and section according to the author's needs: in case of extreme protrusion or statues placed on a bracket, the bars could be one or more, rigid or easily workable, with different thicknesses and shapes, from centimeters to millimeters. The ductility of the metal has allowed the creation of realistic statues, both for hanging very heavy weights as well as for the fine details of fingers or fabrics.

- The Mg-lime produced by firing dolomitic limestones, typical for the area, was used as the main binder. The lack of underburned and overburned particles confirmed the great knowledge of the materials, their production and preparation. The binder particles of gypsum indicate that the firing conditions of the gypsum stone were kept uniform and low.

- The low porosity, the absence of fractures and cracks both in the ground layer and in the finishing, despite their diverse composition, proves the great skills of these artists. Similar mixtures of gypsum, Mg-lime, sand, marble powder and organic additives were expertly dosed in order to create different effects.

- The sand was strictly of local origin with a different composition and particle size for each case study, depending on the available local geological materials. This means that the plasterers could use any type 
of available sand. On the contrary, the size of the crushed marble or calcite crystals, was on purpose kept below $1 \mathrm{~mm}$ size. Finally, the joint between the ground and the finishing mortar was almost invisible, suggesting the so-called "wet over wet" application.

At second instance, the identification of materials and techniques was carried out with the aims of underlining any analogies or peculiarities of the individual authors or family workshops. In this context, general characteristics of the stuccos made by the Silva family have been identified in detail, given the great availability of samples, documents and case studies; the considerations that can be made for the other families are limited and need further study. Indeed, for some authors the well documented case studies in the Ticino region are sporadic and the small number of samples does not allow us to reach definitive conclusions. However, it is not possible to identify a direct correspondence between one "recipe" and the author. In this sense, superficial conclusions must be absolutely avoided, as the mix of components vary both from artist to artist and within the same work of a single artist. An artist is characterized by the general technique used rather than the material he used.

- The visual observation of the restorers and the radiographic images showed that the support structures, although made with the same materials, are used in a peculiar way by the authors. Agostino Silva used the different elements following a homogeneous scheme: the first sketch of the shape is made with bricks and mortar clamped in the masonry, molded wire rods were used for the creation of large volumes, thin iron wires covered with fabrics for fine details. Alessandro Casella used disordered internal structures instead, but with the ability of adapting the mortars spontaneously without a rigid technique. It cannot be excluded that he also used other materials such as wood, but direct evidence was not found. Giovan Antonio Colomba kept his sculptures firmly stable on shelves and therefore did not need to use complex devices to support high weights. Its structures are very simple and essential but extremely effective.

- Complementary analytical techniques confirmed that the mortars used by the different families of authors were made using almost similar components: namely lime, gypsum, sand and organic substances such as egg yolk or milk. The main differences among the artists are in the proportions of gypsum in the ground layer and in the use of the aggregate in the finishing one.

- The Silva workshop used a lime-gypsum mortar for the ground layer while the finishing layer was made of lime and marble powder. The gypsum-lime mortar provided a quicker setting and allowed a stronger bond between the protruding elements and the masonry. A lime-rich mortar was used for the outside layer for giving the final appearance. GB Casella did not use gypsum in the ground layer and used marble powder in the lime finishing. On the contrary, Alessandro Casella, used a lot of gypsum in his work in the Ticino region but not in the San Lorenzo Church of Fusine. His finishes were always made with only lime without the use of aggregate. Finally, Giovanni Antonio Colomba used little or no gypsum in the ground layer and no aggregate for the finishing.

To conclude, it is necessary to underline the importance that the collaboration between researchers from different disciplines has played; thanks to the precious observations of the restorers and a scrupulous archive research it was possible to obtain significant scientific results and interpretation.

\section{Supplementary information}

Supplementary information accompanies this paper at https://doi. org/10.1186/s40494-020-00446-4.

Additional file 1. Datasheet of the Oratory of San Rocco, Bissone (TI). Additional file 2. Datasheet of the Church of San Giorgio, Carona (TI). Additional file 3. Datasheet of the Church of Sant'Eusebio, Castel San Pietro (TI).

Additional file 4. Datasheet of the Oratory Imbonati, San Fermo, (Como, Italy).

Additional file 5. Datasheet of the Church of San Bartolomeo, Domaso (Como, Italy).

Additional file 6. Datasheet of the Church of San Lorenzo, Fusine (Sondrio, Italy).

Additional file 7. Datasheet of the Church of Santa Maria dei Miracoli, Morbio Inferiore ( $\mathrm{Tl})$.

Additional file 8. Datasheet of the Church of Sant'Anna, Morbio Superiore (TI).

Additional file 9. Datasheet of the Church of Sant'Antonino, Obino (TI).

Additional file 10. Datasheet of the Sanctuary of the Sacro Monte, Ossuccio (Como, Italy).

Additional file 11. Datasheet of the Church of Santa Maria d'Ongero, Carona (TI).

Additional file 12. Datasheet of the Church of San Salvatore, Vercana (Como, Italy).

Additional file 13. Datasheet of the Church of Madonna del Carmelo, Villa Coldrerio (TI).

Additional file 14. Datasheet of the Church of Santo Stefano, Arogno (TI).

\section{Abbreviations}

SEM-EDS: Scanning electron microscopy with energy dispersive spectroscopy; FT-IR: Fourier transform infrared spectroscopy; ATR-FTIR: Attenuated Total Reflectance FTIR; BRPs: Binder related particles. 


\section{Acknowledgements}

This research was carried out within the project "The art and industry of plasterers of Ticino from the $16^{\text {th }}$ to the $17^{\text {th }}$ century" funded by the Swiss National Fund (SNSF), grant project number 100016_160092.

The authors wish to acknowledge Alberto Felici and Giovanni Nicoli for the technical analyses, the help in the selection of samples and in the interpretation of scientific data; Dr. Lucia Aliverti for the archival research; Stefania Luppichini for the technical support; Chiara Nesta for the image analyses; Prof. Arch. Giacinta Jean for supervising the work, the organization of the historical data and the revision of the text. We also would like to thank Antonella Ruffolo for the revision of the English language. Furthermore, we are grateful to the anonymous Reviewers for their comments that have improved the paper.

\section{Authors' contributions}

MC: organization and writing of the manuscript, petrographic analyses. SZ: FT-IR analyses on stucco samples. GC: petrographic analyses, sand provenance results, revision of the text. TR: Radiographic analyses. All authors read and approved the final manuscript.

\section{Funding}

This research was funded by the Swiss National Fund (SNSF) Grant project number 100016_160092.

\section{Availability of data and materials}

The datasets on which the manuscript conclusions are based have been organized into schematic datasheets and for 225 samples the detailed descriptions and their location have been made available as supplementary materials.

\section{Competing interests}

No competing interests are involved in this manuscript.

\section{Author details}

${ }^{1}$ Institute of Materials and Construction (IMC), University of Applied Sciences and Arts of Southern Switzerland (SUPSI), Campus Trevano, CH-6952 Canobbio, Switzerland. ${ }^{2}$ Art Technological Laboratory HKB, Bern University of Applied Sciences, Fellerstr. 11, CH-3027 Bern, Switzerland. ${ }^{3}$ Radelet Thierry Private Company, Torino, Italy.

Received: 22 May 2020 Accepted: 5 October 2020 Published online: 16 October 2020

\section{References}

1. Gapper C. What Is "Stucco"? English interpretations of an Italian term. Archit Hist. 1999;42:333-43.

2. Della Torre S. Magistri d'Europa. Eventi, relazioni, strutture della migrazione di artisti e costruttori dai laghi lombardi, (1997) Atti del convegno internazionale. Como, 23-26 Ottobre 1996. Nodo Libri.

3. Marconi N. La cultura materiale del cantiere barocco romano e il ruolo delle maestranze lombarde: metodi, tecniche e apparati. Arte Lombarda. 2000;130:103-7.

4. Damiani Cabrini L. Le migrazioni d'arte. In: Ceschi R, editor. Storia della Svizzera italiana. Dal Cinquecento al Settecento: Bellinzona; 2000. p. 289-312.

5. Casey C. Making Magnificence Architects Stuccatori and the Eighteenthcentury Interior. New Haven: Yale University Press; 2017. p. 55-81.

6. Montana G, Ronca F. The "recipe" of the stucco sculptures of Giacomo Serpotta. J Cult Herit. 2002;3(2):133-44.

7. Rampazzi L, Rizzo B, Colombo C, Conti C, Realini M, Bartolucci U, Colombin MP, Spiriti A, Facchin L. The stucco decorations from St. Lorenzo in Laino (Como, Italy): the materials and the techniques employed by the "Magistri Comacini". Anal Chim Acta. 2008;630(1):91-100.

8. Caroselli M, Cavallo G, Felici A, Aliverti L, Luppichini S, Jean G, Nicoli G. Characterisation of the stucco decorations at the "Sacro Monte di Ossuccio" $\left(16^{\text {th }}-17^{\text {th }}\right.$ century), Como, Italy. Int J Conserv Sci. 2016;7(2):857-70.

9. Bartz W, Kierczak J, Gasior M, Zboińska K. Analytical overview of different Baroque plastering techniques applied in the post-Cistercian abbey in Lubiąż (South-Western Poland). J Cult Herit. 2017;28:37-47.
10. Válek J, Skružná O, Kozlovcev P, Frankeová D, Mácová P, Viani A, Kumpová I. Composition and technology of the 17th century stucco decorations at Červená Lhota Castle in Southern Bohemia. Int J Archit Herit. 2020;14:1-16.

11. Jean G, Felici A, Caroselli M, Nicoli G. Le decorazioni a stucco nella Regione dei laghi: un progetto per lo studio delle tecniche artistiche In: Stucchi e stuccatori ticinesi tra XVI e XVII secolo. Studi e ricerche per la conservazione. Nardini editore; 2020. p. 11-28.

12. Agustoni E, Bianchi F. I Casella di Carona. Lugano: Fidia; 2002.

13. Gavazzi NS, Magni MC. Una traccia per Francesco Silva stuccatore ticinese. Arte Lombarda. 1972;37:86-95.

14. Pedrini SL. I Colomba di Arogno. Lugano: Fidia; 1994.

15. Aliverti L, Felici A, Jean G. L'impresa dei Silva di Morbio Inferiore, atti del convegno di studi Pratiche architettoniche a confronto nei cantieri italiani della seconda metà del Cinquecento. M.F. Nicoletti, P.C. Verde (a cura di), Mendrisio, Archivio del Moderno, Milano, Officina Libraria; 2019. p. 97-118.

16. Pavía S, Carò S. An investigation of Roman mortar technology through the petrographic analysis of archaeological material. Constr Build Mater. 2008;22(8):1807-11.

17. Carò F, Di Giulio A. Reliability of textural analysis of ancient plasters and mortars through automated image analysis. Mater Charact. 2004;53(2-4):243-57.

18. Rampazzi L, Colombini MP, Conti C, Corti C, Lluveras-Tenorio A, Sansonetti A, Zanaboni M. Technology of medieval mortars: an investigation into the use of organic additives. Archaeometry. 2016;58(1):115-30.

19. Zumbühl S, Scherrer N, Eggenberger U. Derivatization technique to increase the spectral selectivity of two-dimensional fourier transform infrared focal plane array imaging: analysis of binder composition in aged oil and tempera paint. Appl Spectrosc. 2014;68:458-65.

20. Cavallo G., Biondelli D. The use of magnesian lime in historical mortars in Tessin Canton, Switzerland: microscopical features and microanalytical evidences. In: Proceedings VII Congresso Associazione Italiana di Archeometria. 2012. p. 22-4.

21. Elsen J. Microscopy of historic mortars-a review. Cem Concr Res. 2006;36(8):1416-24

22. Amoretti C. Viaggio da Milano ai tre Laghi, Maggiore, di Lugano e di Como e ne' monti che li circondano. Milano: Giuseppe Galeazzi; 1824.

23. Blumenbach JF. Handbuch der Naturgeschichte, J.C. Dieterich, Göttingen, 1779-1780, 2 vols.; It. transl. Manuale di storia naturale,Vanelli e comp., Lugano, 1825, 2 vols.

24. Schneiderfranken I. Ricchezze del suolo ticinese: studio economico sullo sfruttamento delle pietre da costruzione e delle materie prime minerali. Istituto editoriale ticinese; 1943.

25. Jean G., Aliverti L., Felici A. Gli stuccatori ticinesi al lavoro: fonti d'archivio ed evidenze materiali (2016) Oral communication, Conference"Materia e costruzione. Le parole del cantiere", Roma, 21-22 Nov. 2016

26. Caroselli M, Cavallo G, Felici A, Luppichini S, Nicoli G, Aliverti L, Jean G. Gypsum in Ticinese stucco artworks of the 16-17th century: Use, characterization, provenance and induced decay phenomena. J Archaeol Sci Rep. 2019:24:208-19.

27. Natali C, Lorenzini G. Degradi e metodi di conservazione dello stucco: analisi e progetti per l'Oratorio Imbonati di Cavallasca. Arkos. 2000;1 (1):50-8.

28. Felici A., Nicoli G., Caroselli M., Luppichini L., Cigognetti E., Dottore A. L'intervento di restauro degli stucchi dell'oratorio Imbonati a Cavallasca (2020) In: Jean G. and Felici A. Nardini Ed. Firenze eds. Stucchi e stuccatori ticinesi tra XVI e XVIII secolo. Studi e ricerche per la conservazione, pp. $191-223$.

29. Cavallo G, Caroselli M, Aliverti L, Felici A, Jean G, Nicoli G, Luppichini S. Research on 17th c. stucco decorations by the Silva family workshop in the Basilica Santa Maria dei Miracoli in Morbio Inferiore (Tessin). In Proceedings of HMC2016 historic mortars conference, October 2016. p. 10-2.

30. Rampazzi L, Rizzo B, Colombo C, Conti C, Realini M, Bartolucci U, Colombini MP, Spiriti A, Facchin L. The Stucco Technique of the Magistri Comacini: the Case Study of Santa Maria Dei Ghirli in Campione D'italia (Como, Italy). Archaeometry. 2012;54(5):926-39.

31. Aksamija A, NowikW, Lehuédé P, Le Hô A-S, Bormand M, Bouquillon A. Investigation of organic additives in Italian Renaissance devotion stucco reliefs from French collections. J Cult Herit. 2019;39:66-81.

32. Jean G., Felici A., Aliverti L., Caroselli M., Nicoli G., Cavallo G., Luppichini S. Arte e tecnica dello stucco in Ticino. II Modus operandi degli artisti attivi tra Lugano e Mendrisio dal XVI al XVII secolo (in press) 
33. Rampazzi L. Calcium oxalate films on works of art: a review. J Cult Herit. 2019:40:195-21414.

34. Wentworth CK (1922) A scale of grade and class terms for clastic sediments. J Geol 30:377-392

\section{Publisher's Note}

Springer Nature remains neutral with regard to jurisdictional claims in published maps and institutional affiliations.
Submit your manuscript to a SpringerOpen ${ }^{\odot}$ journal and benefit from:

- Convenient online submission

- Rigorous peer review

- Open access: articles freely available online

- High visibility within the field

- Retaining the copyright to your article

Submit your next manuscript at $\boldsymbol{\nabla}$ springeropen.com 